\title{
REVIEW
}

\section{The uncoupling proteins, a review}

\author{
Olivier Boss, Patrick Muzzin and Jean-Paul Giacobino \\ Medical Biochemistry, Faculty of Medicine, University of Geneva, 1 Michel Servet, 1211 Geneva 4, Switzerland \\ (Correspondence should be addressed to O Boss)
}

\section{Emergence of a new uncoupling protein family}

The uncoupling protein-1 (UCP1), cloned in 1985 (14) and called UCP until 1997, is an inner mitochondrial membrane protein (5) expressed exclusively in the brown adipocyte (6-8). It dissipates the mitochondrial proton $\left(\mathrm{H}^{+}\right)$gradient generated by the respiratory chain, producing heat instead of $\operatorname{ATP}(8,9)$.

In rodents the brown adipose tissue (BAT) contributes to both the maintenance of body temperature in a cold environment through nonshivering thermogenesis and the control of body weight through the regulatory (or facultative) part of diet-induced thermogenesis $(10,11)$. It has been shown that during cold acclimation the capacity of brown adipocytes to produce heat is determined by the UCP1 content of their mitochondria (12-14).

Several observations led to the hypothesis that there could exist uncoupling proteins in tissues other than BAT. First, adult humans, who possess very little active BAT $(15,16)$, produce heat in their skeletal muscle in response to glucose or catecholamine administration (17-20). Secondly, mitochondrial $\mathrm{H}^{+}$leaks have been observed in tissues devoid of UCP1 (21-23). They may account for up to $50 \%$ of the oxygen consumption of some tissues $(24,25)$, and up to $30 \%$ of whole body metabolic rate in the rat (24-26). It was suggested that the $\mathrm{H}^{+}$leak was related to resting metabolic rate $(27$, 28). Supporting the previous observations, several groups independently cloned novel UCPs, i.e. UCP2 $(29-31)$ and UCP $3(31,32)$. UCP 2 is expressed in most tissues studied in humans and rodents, and UCP3 mainly in skeletal muscle in humans, and BAT and skeletal muscle in rodents (31). UCP1, which was thought to be a protein unique to BAT, is in fact a member of an emerging family of uncoupling proteins expressed in humans and animals, and even in plants $(33,34)$.

\section{Are UCP2 and UCP3 mitochondrial uncoupling proteins?}

Several arguments suggest that UCP2 and UCP3, like UCP1, are inner mitochondrial membrane proteins. Their amino acid sequences display a significant similarity only to those of mitochondrial transporters (31). The three UCPs share several characteristics with mitochondrial carriers (35). They are about 300 amino acids long and have a molecular mass of $30 \mathrm{kDa}$. Each of the three UCPs has three typical mitochondrial energy transfer protein signatures (PROSITE PSO0215 (31, 36)), which can be used to identify potential mitochondrial carriers from amino acid sequences (35), and their sequences show a triplicate structure of a 100-amino acid domain. The genomic structure of $\mathrm{UCP} 3(37,38)$, with six coding exons, is similar to that of UCP1 (39, 40). Numerous lines of evidence indicate that UCP2 and UCP3 are real uncoupling proteins. In the family of mitochondrial carriers UCP2 and UCP3 have the highest predicted amino acid sequence homology to UCP1. Both human UCP2 $(29,30)$ and UCP $3(41,42)$ have been shown to decrease the mitochondrial electrochemical potential in transformed yeast or in transfected $\mathrm{C}_{2} \mathrm{C}_{12}$ mouse myoblasts.

Thus, although the mitochondrial location and the heat-producing activity of UCP2 and UCP3 in mammalian cells have still to be demonstrated directly, it is very likely that these proteins act, like UCP1, as mitochondrial uncoupling proteins by dissipating the mitochondrial $\mathrm{H}^{+}$gradient produced by the respiratory chain.

\section{Regulation of UCP1, UCP2 and UCP3 gene expression}

\section{What is known about UCP1}

The expression of UCP1 is regulated at the transcriptional level (43), and its control has been extensively studied $(35,44)$ (Table 1). Norepinephrine is a strong physiological activator of UCP1 expression $(45,46)$, and activation of the $\beta_{1^{-}}, \beta_{2^{-}}, \beta_{3^{-}}$and $\alpha_{1^{-a d r e n e r g i c}}$ receptors $(46-48)$ as well as inhibition of the $\alpha_{2^{-}}$ adrenergic receptor (49) has been shown to increase the expression of UCP1. The thyroid hormone tri-iodothyronine $\left(\mathrm{T}_{3}\right)$ has been reported to act as a permissive factor for the full induction of UCP1 gene expression by norepinephrine $(50,51)$.

The expression of UCP1 is also increased by retinoic acid (52-54) and by peroxisome proliferator-activated receptor (PPAR) agonists like thiazolidinediones (5557). 
Table 1 Regulation of UCP1 mRNA expression in BAT.

\begin{tabular}{|c|c|}
\hline Condition & $\begin{array}{l}\text { Change in UCP1 mRNA } \\
\text { (reference) }\end{array}$ \\
\hline Cold & $\uparrow(46,114)$ \\
\hline Thermoneutrality & $\downarrow(115-117)$ \\
\hline Fasting $(24-48 \mathrm{~h})$ & $\downarrow(118-120)$ \\
\hline Food restriction & $\downarrow(121$, Cusin et al., unpublished) \\
\hline Refeeding (24 h) & $\uparrow(118)$ \\
\hline High fat diet & $\uparrow(122)$ \\
\hline Endurance training & $\rightarrow(63,123)$ \\
\hline Obesity & $\downarrow \mathrm{fa} / \mathrm{fa}(46,47), \rightarrow$ ob/ob (46), $\downarrow$ ob/ob (41) \\
\hline Leptin & $\begin{array}{l}\uparrow(121, \text { Cusin et al., unpublished), } \\
\uparrow o b / o b(41)\end{array}$ \\
\hline Hypothyroidism & $\downarrow(124,125)$ \\
\hline Thyroid hormone $\left(T_{3}\right)$ & $\uparrow(50,124)$ \\
\hline Glucocorticoids & $\downarrow(126-128)$ \\
\hline Insulin (3h) & $\uparrow(127,129)$ \\
\hline Ro $16-8714$ (30 h) & $\uparrow \mathrm{fa} / \mathrm{fa}(47)$ \\
\hline CL 316,243 & $\uparrow(130-132)$ \\
\hline
\end{tabular}

$\mathrm{fa} / \mathrm{fa}=$ obese $\mathrm{fa} / \mathrm{fa}$ Zucker rats, $o b / o b=$ obese $o b / o b \mathrm{C} 57 \mathrm{BL}$ mice.

\section{The expression of UCP3 varies like that of UCP1 in BAT}

As shown in Tables 1 and 2, changes in environmental temperature $(42,58$, and $\mathrm{O}$ Boss, $\mathrm{H}$ Ghezraoui, J Seydoux, J-P Giacobino \& P Muzzin P, unpublished observations), variations in food intake $(41,42$, and I Cusin, K E Zakrzewska, O Boss, P Muzzin, J P Giacobino, D Ricquier, B Jeanrenaud \& F Rohner-Jeanrenaud, unpublished observations), and administration of $\mathrm{T}_{3}$ $(41,58)$ or glucocorticoids $(41)$ affect identically UCP3 and UCP1 mRNA expressions in BAT. One exception is the absence of effect of the $\beta_{3}$-adrenergic agonist CL 316,243 on UCP 3 mRNA expression in BAT reported by Gong et al. (41).
In the BAT of hereditary obese $o b / o b$ mice (41) and $f a / f a$ rats $(42,46,47)$ both UCP1 and UCP3 mRNA expressions are decreased compared with lean controls. The administration of leptin to $o b / o b$ mice increases BAT UCP1 and UCP3 mRNA levels (41).

These observations support the hypothesis that both UCP 3 and UCP1 contribute to thermogenesis in BAT.

As shown in Table 3, UCP2 in BAT differs from UCP1 and UCP3 in the way its expression varies with metabolic changes. For instance UCP2 mRNA expression in BAT is insensitive to fasting $(41,59)$, refeeding (41) and administration of glucocorticoids (41).

In BAT as well as in white adipose tissue (WAT) UCP2 mRNA expression is increased in all rodent models of hereditary obesity tested so far $(30,41$, and $\mathrm{O}$ Boss $\mathrm{O}, \mathrm{P}$ Muzzin, F Assimacopoulos-Jeannet \& J P Giacobino, unpublished observations), and a significant positive correlation has been reported between UCP2 mRNA levels in WAT and body mass index in humans (60). The pattern of regulations of UCP2 expression supports the idea that UCP 2 might have functions other than that of thermogenesis.

\section{The expression of UCP3 often varies in opposite directions in skeletal muscle vs BAT}

In contrast to what is observed in BAT, changes in environmental temperature do not affect UCP3 mRNA expression in skeletal muscle (42). These results are in line with the notion that muscle is not involved in nonshivering thermogenesis in rodents.

It has been shown that after 10 days of food restriction $(50 \%)$ and during the refeeding phase thereafter the metabolic efficiency of rats is increased and remains elevated until the animals have recovered their body fat stores (61). There are two components in

Table 2 Regulation of UCP3 mRNA expression in skeletal muscle and BAT.

\begin{tabular}{|c|c|c|}
\hline \multirow[b]{2}{*}{ Condition } & \multicolumn{2}{|c|}{ Change in UCP3 mRNA (reference) } \\
\hline & Skeletal muscle & BAT \\
\hline Cold (48 h, 10 days) & $\rightarrow(31,42,58)$ & $\uparrow(58,42)$ \\
\hline Thermoneutrality & $\rightarrow(42)$ & $\downarrow$ (Boss et al., unpublished) \\
\hline Fasting (24-48 h) & $\uparrow(41,42,67)$ & $\downarrow(41,42)$ \\
\hline Severe food restriction ( $90 \%)$ & $\uparrow(60)$ & - \\
\hline Food restriction $(40-50 \%)$ & $\downarrow$ (42, Cusin et al., unpublished) & $\downarrow$ (Cusin et al., unpublished) \\
\hline Refeeding $(24 \mathrm{~h})$ & $\downarrow(41)$ & $\uparrow(41)$ \\
\hline High fat diet & $\rightarrow(58), \uparrow(133)$ & $\uparrow(58, \rightarrow(133)$ \\
\hline Endurance training & $\downarrow(63)$ & $\rightarrow(63)$ \\
\hline Obesity & $\downarrow$ fa/fa (42), $\rightarrow$ ob/ob (41) & $\downarrow$ fa/fa (42), $\downarrow$ ob/ob (41) \\
\hline Leptin & $\uparrow$ (Cusin et al., unpublished), $\uparrow$ ob/ob (41) & $\uparrow$ (Cusin et al., unpublished), $\uparrow$ ob/ob (41) \\
\hline Hypothyroidism & $\downarrow(41)$ & $\rightarrow(41)$ \\
\hline Thyroid hormone $\left(T_{3}\right)$ & $\uparrow(41,58)$ & $\uparrow(41,58)$ \\
\hline Glucocorticoids & $\uparrow(41), \rightarrow(67)$ & $\downarrow(41)$ \\
\hline Insulin (3h) & $\rightarrow(60)$ & - \\
\hline Ro $16-8714$ (30h) & $\uparrow, \uparrow$ fa/fa (Boss et al., unpublished) & $\uparrow, \uparrow f a / f a$ (Boss et al., unpublished) \\
\hline CL 316,243 & $\rightarrow(41)$ & $\rightarrow(41)$ \\
\hline
\end{tabular}

$f a / f a=$ obese $f a / f a$ Zucker rats, ob/ob = obese ob/ob C57BL mice. 


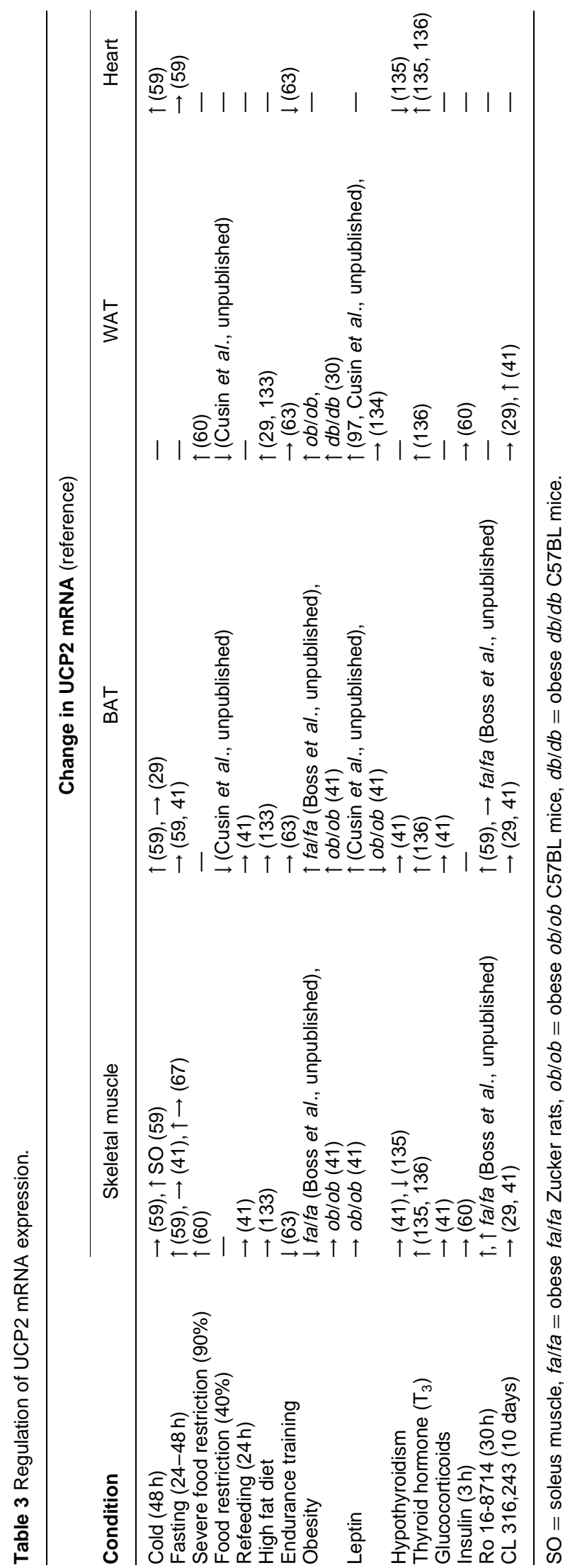

this enhanced metabolic efficiency (62). The first component is due to a decrease in BAT sympathetic activity during food restriction, and this activity goes back to control levels within 1 day of refeeding. The second component seems to be muscular, and persists for as long as the body fat stores have not been recovered. In fact, in rodents the levels of UCP3 mRNA decrease both in BAT (O Boss, H Ghezraoui, J Seydoux, J P Giacobino \& P Muzzin P, unpublished observations) and skeletal muscle (42, and O Boss, H Ghezraoui, J Seydoux, J P Giacobino \& P Muzzin P, unpublished observations) after food restriction and, during refeeding, go back to control levels within 1 day in BAT (41), but remain very low (or decrease even further) in skeletal muscle (41).

During endurance exercise training a decrease in metabolic rate should allow for a better reconstitution of energy stores between exercise bouts. Also under this condition UCP 3 mRNA expression has been shown to be decreased in skeletal muscle (63).

These findings support the hypothesis that futile cycles (via UCP3) are turned off in muscle under metabolic conditions which dictate sparing of energy.

The mechanisms of the above-described decreases in UCP3 mRNA expression in skeletal muscle are not yet understood, but some hypotheses can be proposed. Circulating levels of insulin should be decreased by food restriction, but this hormone does not seem to affect UCP3 mRNA expression in muscle (60). Insulin is therefore an unlikely mediator of the effect of food restriction on UCP3 expression in muscle. The levels of $\mathrm{T}_{3}$ should be decreased by food restriction (64-66), and it has been shown that hypothyroidism decreases (41) and administration of $\mathrm{T}_{3}$ increases $(41,58) \mathrm{UCP} 3 \mathrm{mRNA}$ expression in skeletal muscle. Thus, $\mathrm{T}_{3}$ might play a role in the effects of food restriction on UCP 3 expression.

An unexpected exception in this pattern of regulations in skeletal muscle is fasting or severe food restriction. In contrast to what is observed after 4-7 days of $40-50 \%$ food restriction $(42$, and $\mathrm{O}$ Boss, $\mathrm{H}$ Ghezraoui, J Seydoux, J P Giacobino \& P Muzzin P, unpublished observations), $24-48 \mathrm{~h}$ of fasting in rodents $(41,42,67)$ or 5 days of severe $(90 \%)$ food restriction in humans (60) increases dramatically UCP3 mRNA expression in muscle.

This increase in UCP3 gene expression could be mediated by free fatty acids (FFAs), whose circulating levels rise during fasting but not during moderate food restriction. Very recently Weigle et al. (67) showed that increased plasma levels of FFAs to $2.0 \mathrm{mmol} / \mathrm{l}$ induced by Intralipid and heparin administration for $28 \mathrm{~h}$ in rats caused a rise in UCP3 mRNA expression in skeletal muscle similar to that observed after a 28 -h fast. In obese humans the results of a recent study suggest that FFAs play a role in the regulations of muscle UCP3 expression, as a significant positive correlation was found between the level of plasma FFA and that of UCP3 mRNA in vastus lateralis muscle (O Boss, E Bobbioni-Harsch, 
F Assimacopoulos-Jeannet, $\mathrm{P}$ Muzzin, R Munger, J P Giacobino \& A Golay, unpublished observations). As FFAs are ligands for PPAR $\gamma$, the latter might be expected to mediate the effects of FFA on UCP3 expression in muscle (67). In fact it has been shown recently that $\mathrm{UCP} 2$ mRNA expression is enhanced by PPAR $\gamma$ agonists in pancreatic islets (68) as well as in cultured white adipocytes $(69,70)$, brown adipocytes (70) and myocytes (70). The UCP2 and UCP3 gene promoters therefore probably contain, like that of UCP1 (55, 44, 71), PPAR $\gamma$-response elements $(67,68)$. The decrease in circulating leptin levels induced by fasting might play a role in the increase of muscle UCP 3 mRNA expression. Weigle et al. (67) showed that maintenance of supraphysiological levels of circulating leptin during a 48-h fast does not alter the rise in UCP 3 mRNA levels in muscle. Furthermore, this rise could not be mimicked by the administration of pharmacological doses of the glucocorticoid cortisol. Thus, neither leptin nor glucocorticoids seems to play a role in the fasting-induced increase in UCP3 mRNA levels in muscle.

In hereditary obese rodents UCP 3 mRNA expression in BAT is decreased in both $f a / f a$ rats (42) and $o b / o b$ mice (41), whereas in muscle it is either decreased in $f a / f a$ rats (42) or unchanged in $o b / o b$ mice (41).

\section{Regulation of UCP, UCP2 and UCP3 activity}

UCP1 contains six potential transmembrane $\alpha$-helices (72) and acts under the form of a homodimer (73). Its uncoupling activity is increased by FFA (74-77) and by long chain fatty acyl CoA esters $(78,79)$, and decreased by purine nucleotide di- or tri-phosphates $(12,74)$. The mechanism of action of UCP1 is still a matter of controversy. One model proposes that deprotonated fatty acid anions are transported by UCP1 and the protonated form traverses the phospholipid bilayer of the membrane $(80,81)$. The other model proposes that FFAs bind UCP1, and their carboxyl groups serve as $\mathrm{H}^{+}$ donors (82). In the second model fatty acids are not translocated through the membrane. In both models protonation/deprotonation of fatty acid carboxyl groups participate in $\mathrm{H}^{+}$transport.

The mechanism of UCP1 activation by fatty acids has not yet been elucidated (35). Mutagenesis experiments have shown that cysteine residue 305 on rat UCP1 plays an important but not essential role in this activation (83). This cysteine is absent in UCP2 and UCP3, and it is presently not known whether or not fatty acids modulate UCP2 and/or UCP3 activity.

Although specific amino acid residues of UCP1 have been reported to contribute to the binding of GDP, the full GDP-binding domain has not yet been clearly defined. It seems that residues from different parts of the protein play a role in this interaction $(35,84-92)$. Although almost all the residues reported to be essential for the binding of GDP by UCP1 are conserved in UCP2 and UCP3, the potential control by GDP of UCP2 and UCP3 activities remains to be demonstrated.

\section{Physiological relevance of UCP1, UCP2 and $U C P 3$, and their potential role in human disease}

\section{Possible role of UCP2 in the maintenance of low levels of oxygen and oxygen radicals}

Under resting conditions energy consumption is low and the availability of ADP for phosphorylating respiration decreases, which may result in an increase in intracellular levels of $\mathrm{O}_{2}$ and one-electron $\mathrm{O}_{2}$ reductants (93). These conditions could enhance the formation of reactive oxygen species (ROS), e.g. superoxide anion, hydrogen peroxide and hydroxyl radical, and then cause oxidative damage within the cell. It has been proposed by Skulachev (93) that nonphosphorylating (uncoupled or noncoupled) mitochondrial respiration allows the maintenance of low levels of both $\mathrm{O}_{2}$ and ROS when phosphorylating respiration fails to do so due to a lack of ADP. An increase in the $\mathrm{H}^{+}$leak of the mitochondrial membrane in State 4 (without available ADP) would thus stimulate $\mathrm{O}_{2}$ consumption and decrease the formation of ROS (93).

A role for UCP2 as a regulator of mitochondrial hydrogen peroxide generation has been proposed by Nègre-Salvayre et al. (94). The authors showed that addition of the UCP1 inhibitor GDP to mitochondrial fractions from liver nonparenchymal cells or from BAT, which both highly express UCP 2 mRNA, raises both the mitochondrial membrane potential and hydrogen peroxide production. GDP was completely ineffective on mitochondria from hepatocytes, which are deficient in UCP2 (94). The authors suggested that UCP2 activity is inhibited by GDP and that UCP2 is able to modulate hydrogen peroxide formation, supporting a role for UCP2 in the control of cellular processes involving free radicals generated by mitochondria, such as oxidative damage, inflammation, or apoptosis (94).

\section{UCP2 and insulin secretion}

Glucose-induced insulin secretion by pancreatic islet cells has been shown to require mitochondria (95), and to involve an increase in the cellular ATP/ADP ratio (96). UCP2 is expressed in pancreatic islets (97) and might, by decreasing the cellular ATP levels, blunt glucose-induced insulin secretion. Leptin, which decreases the insulin response to glucose and other fuels (98), was found to increase UCP2 mRNA expression in pancreatic islets (97). It can be hypothesized that a high level of UCP2 could decrease insulin secretion.

In obese diabetic rodents defects in insulin secretion are often associated with hyperlipidemia and increased triglyceride content in pancreatic islets $(97,99)$. It can 
be hypothesized that increased levels of FFAs in pancreatic islet cells may enhance UCP2 expression, and in turn, impair insulin secretion. The effect of FFA on UCP2 gene expression might be mediated by PPAR $\gamma$ since troglitazone has been shown to increase UCP2 mRNA levels in pancreatic islets (68).

\section{UCP1, UCP2 and UCP3 as obesity gene candidates}

In most genetically obese rodents BAT is poorly active (35) and the level of UCP1 mRNA and/or UCP1 is generally lowered (46).

Lowell et al. (100) obtained transgenic mice with severely reduced BAT mass using a suicide transgene encoding the diphtheria toxin A chain (DTA) downstream from the UCP1 promoter. The transgenic UCP1DTA mice developed obesity and then hyperphagia, diabetes and hyperlipidemia $(100,101)$. On the other hand, Kopecky et al. (102) observed in obese transgenic mice expressing UCP1 in their WAT (aP2-UCP1 transgene) a decrease in body weight and in WAT. UCP1-knockout mice were found to be cold-sensitive but neither hyperphagic nor obese (103). This suggests that UCP1 plays an essential role in cold-induced thermogenesis. The fact that UCP1-knockout mice did not become hyperphagic and obese suggests either that UCP1 is not essential for the control of body weight or that its absence can be compensated for by other dissipating pathways. An increase in UCP2 mRNA expression was observed in BAT of UCP1-knockout mice (103), and a possible compensatory role of UCP 3 in BAT and/or in skeletal muscle has not yet been tested. These studies suggest that a functional BAT, but not UCP1, is essential to prevent the development of obesity in rodents. On the other hand, ectopic expression of UCP1 in WAT induces body fat loss.

In humans, a polymorphic BclI site (104) resulting from an $\mathrm{A} / \mathrm{G}$ mutation (105) has been described in the 5'-flanking region of the UCP1 gene. This polymorphic site was reported to correlate significantly with the percentage of body fat gain over time (104), to be a predictive factor associated with high weight gain during adult life in morbidly obese subjects (106), and to be associated with a low body weight loss after caloric restriction (107). These studies suggest that UCP1 may play a role in energy balance and weight gain in humans.

In addition, five different amino acid polymorphisms in UCP1 (R/W40, A/T64, V/M137, M/L229 and K/N257) and two nucleotide substitutions in the nontranslated region of exon 1 have been reported (108). However, none of these polymorphisms seems to be a common factor contributing to obesity in the population studied (108).

Because UCP2 and UCP3 might be involved in energy dissipation they might participate in weight regulation. Mutations in their genes could play a role in the development of obesity and/or noninsulin-dependent diabetes. A significant linkage between flanking markers in the vicinity of the UCP2 gene and resting metabolic rate in a Canadian population has been reported by Bouchard et al. (109), whereas no significant linkage was found with body mass index or central adiposity in Northern European, type 2 diabetic patients (110). A common amino acid polymorphism (A/V55) in UCP2 has been found which does not seem to be implicated in the pathogenesis of obesity or insulin resistance in Caucasians of Danish ancestry (111).

The UCP3 gene was shown to lie in the same region as the UCP2 gene, i.e. in $11 \mathrm{q} 13$ between markers D11S916 and D11S911 or D11S3966 (37, 38, 41). Thus, the linkage observed by Bouchard et al. (109) between these markers and resting metabolic rate may be due to variations in the UCP2, UCP 3 or another gene in the vicinity. The identification of polymorphic sequences in the UCP2 and UCP3 genes will allow for more specific linkage studies.

\section{UCP2 and UCP3 as novel targets for anti- obesity and anti-diabetes drugs}

The recent discovery of these novel uncoupling proteins brings new hope to obesity research, as the expression level and/or the activity of these proteins may play a role in the differences in metabolic rates (112) and body fat mass (113) observed between individuals.

Even if no defects in the UCP 2 and UCP 3 genes can be associated with human obesity, these proteins could still represent good targets for drugs aimed at increasing energy expenditure. The maintenance of skeletal muscle UCP3 expression during food restriction and refeeding might prevent the observed increase in food efficiency and might help lose or not regain weight. It could therefore break the vicious circle of what is called the ‘yo-yo' phenomenon.

\section{Acknowledgements}

The authors thank Françoise Kühne, Hanadi Ghezraoui, Frédéric Preitner, Patrick Keller, and the group of Dr Françoise Assimacopoulos-Jeannet. OB was supported by a grant from the Swiss Institute of Sport Sciences. This work was supported by the Swiss National Science Foundation (No. 31-43405.95), by the Ciba-GeigyJubiläums-Stiftung, and by the Fondation du Centenaire de la Société Suisse d'Assurances Générales sur la Vie Humaine pour la Santé Publique et les Recherches Médicales.

\section{References}

1 Bouillaud F, Ricquier D, Thibault J \& Weissenbach J. Molecular approach to thermogenesis in brown adipose tissue: cDNA cloning of the mitochondrial uncoupling protein. Proceedings of the National Academy of Sciences of the USA 198582 445-448. 
2 Jacobsson A, Stadler U, Glotzer MA \& Kozak LP. Mitochondrial uncoupling protein from mouse brown fat. Molecular cloning, genetic mapping, and mRNA expression. Journal of Biological Chemistry $198526016250-16254$.

3 Bouillaud F, Weissenbach J \& Ricquier D. Complete cDNA-derived amino acid sequence of rat brown fat uncoupling protein. Journal of Biological Chemistry 1986261 1487-1490.

4 Ridley RG, Patel HV, Gerber GE, Morton RC \& Freeman KB. Complete nucleotide and derived amino acid sequence of cDNA encoding the mitochondrial uncoupling protein of rat brown adipose tissue: lack of a mitochondrial targeting presequence. Nucleic Acids Research 198614 4025-4035.

5 Cinti S, Zancanaro C, Sbarbati A, Cicolini M, Vogel P, Ricquier D \& Fakan S. Immunoelectron microscopical identification of the uncoupling protein in brown adipose tissue mitochondria Biology of the Cell 198967 359-362.

6 Cannon B, Hedin A \& Nedergaard J. Exclusive occurrence of thermogenin antigen in brown adipose tissue. FEBS Letter $1982150129-132$.

7 Cadrin M, Tolszczuk M, Guy J, Pelletier G, Freeman KB \& Bukowiecki LJ. Immunohistochemical identification of the uncoupling protein in rat brown adipose tissue. Journal of Histochemistry and Cytochemistry 198533 150-154.

8 Klaus S, Casteilla L, Bouillaud F \& Ricquier D. The uncoupling protein UCP: a membraneous mitochondrial ion carrier exclusively expressed in brown adipose tissue. International Journal of Biochemistry 199123 791-801.

9 Cannon B \& Nedergaard J. The biochemistry of an inefficient tissue: brown adipose tissue. Essays in Biochemistry 198520 $110-164$.

10 Rothwell NJ \& Stock MJ. A role for brown adipose tissue in dietinduced thermogenesis. Nature 1979281 31-35.

11 Himms-Hagen J. Brown adipose tissue thermogenesis: interdisciplinary studies. FASEB Journal 19904 2890-2898.

12 Heaton GM, Wagenvoord RJ, Kemp A Jr \& Nicholls DG. Brownadipose-tissue mitochondria: photoaffinity labelling of the regulatory site of energy dissipation. European Journal of Biochemistry $197882515-521$.

13 Hansen ES \& Knudsen J. Parallel measurements of heat production and thermogenin content in brown fat cells during cold acclimation of rats. Bioscience Reports 1986 631-38.

14 Rafael J, Fesser W \& Nicholls DG. Cold adaptation in guinea pig at level of isolated brown adipocyte. American Journal of Physiology 1986250 C228-C235.

15 Cunningham S, Leslie P, Hopwood D, Illingworth P, Jung RT, Nicholls DG, Peden N, Rafael J \& Rial E. The characterization and energetic potential of brown adipose tissue in man. Clinical Science $198569343-348$.

16 Lean ME, James WP, Jennings G \& Trayhurn P. Brown adipose tissue uncoupling protein content in human infants, children and adults. Clinical Science 198671 291-297.

17 Astrup A, Bulow J, Madsen J \& Christensen NJ. Contribution of BAT and skeletal muscle to thermogenesis induced by ephedrine in man. American Journal of Physiology 1985248 E507-E515.

18 Astrup A, Bulow J, Christensen NJ, Madsen J \& Quaade F. Facultative thermogenesis induced by carbohydrate: a skeletal muscle component mediated by epinephrine. American Journal of Physiology 1986250 E226-E229.

19 Astrup A, Simonsen L, Bulow J, Madsen J \& Christensen NJ. Epinephrine mediates facultative carbohydrate-induced thermogenesis in human skeletal muscle. American Journal of Physiology 1989257 E340-E345.

20 Simonsen L, Stallknecht B \& Bulow J. Contribution of skeletal muscle and adipose tissue to adrenaline induced thermogenesis in man. International Journal of Obesity and Related Metabolic Disorders 199317 (Suppl 3) S47-S51; Discussion S68.

21 Brand MD. The proton leak across the mitochondrial inner membrane. Biochimica et Biophysica Acta $1990 \quad 1018$ $128-133$.
22 Nobes CD, Brown GC, Olive PN \& Brand MD. Non-ohmic proton conductance of the mitochondrial inner membrane in hepatocytes. Journal of Biological Chemistry 1990265 12903-12909.

23 Harper ME \& Brand MD. The quantitative contributions of mitochondrial proton leak and ATP turnover reactions to the changed respiration rates of hepatocytes from rats of different thyroid status. Journal of Biological Chemistry 1993268 1485014860 .

24 Brand MD, Chien LF, Ainscow EK, Rolfe DF \& Porter RK. The causes and functions of mitochondrial proton leak. Biochimica et Biophysica Acta 19941187 132-139.

25 Rolfe DF \& Brand MD. Contribution of mitochondrial proton leak to skeletal muscle respiration and to standard metabolic rate. American Journal of Physiology 1996271 C1380-C1389.

26 Rolfe DF \& Brand MD. The physiological significance of mitochondrial proton leak in animal cells and tissues. Bioscience Reports 199717 9-16.

27 Porter RK \& Brand MD. Body mass dependence of $\mathrm{H}^{+}$leak in mitochondria and its relevance to metabolic rate. Nature 1993 $362628-630$.

28 Rolfe DF \& Brown GC. Cellular energy utilization and molecular origin of standard metabolic rate in mammals. Physiological Reviews 199777 731-758.

29 Fleury C, Neverova M, Collins S, Raimbault S, Champigny O, Levi-Meyrueis C, Bouillaud F, Seldin MF, Surwit RS, Ricquier D \& Warden $\mathrm{CH}$. Uncoupling protein-2: a novel gene linked to obesity and hyperinsulinemia. Nature Genetics 199715 269-272.

30 Gimeno RE, Dembski M, Weng X, Deng N, Shyjan AW, Gimeno CJ, Iris F, Ellis SJ, Woolf EA \& Tartaglia LA. Cloning and characterization of an uncoupling protein homolog: a potential molecular mediator of human thermogenesis. Diabetes 199746 900-906.

31 Boss O, Samec S, Paoloni-Giacobino A, Rossier C, Dulloo A, Seydoux J, Muzzin P \& Giacobino JP. Uncoupling protein-3: a new member of the mitochondrial carrier family with tissuespecific expression. FEBS Letters 1997408 39-42.

32 Vidal-Puig A, Solanes G, Grujic D, Flier JS \& Lowell BB. UCP3: an uncoupling protein homologue expressed preferentially and abundantly in skeletal muscle and brown adipose tissue. Biochemical and Biophysical Research Communications 1997235 79-82.

33 Jeek P, Costa ADT \& Vercesi AE. Evidence for anion-translocating plant uncoupling mitochondrial protein in potato mitochondria. Journal of Biological Chemistry 1996271 32743-32748.

34 Laloi M, Klein M, Riesmeier JW, Muller-Rober B, Fleury C, Bouillaud F \& Ricquier D. A plant cold-induced uncoupling protein. Nature 1997389 135-136.

35 Ricquier D \& Bouillaud F. The mitochondrial uncoupling protein: structural and genetic studies. Progress in Nucleic Acid Research and Molecular Biology 199756 83-108.

36 Bairoch A. The PROSITE dictionary of sites and patterns in proteins, its current status. Nucleic Acids Research 199321 3097-3103.

37 Solanes G, Vidal-Puig A, Grujic D, Flier IS \& Lowell BB. The human uncoupling protein-3 gene. Genomic structure, chromosomal localization, and genetic basis for short and long form transcripts. Journal of Biological Chemistry 1997272 2543325436.

38 Boss O, Giacobino JP \& Muzzin P. Genomic structure of uncoupling protein-3 (UCP3) and its assignment to chromosome 11q13. Genomics $199847425-426$.

39 Kozak LP, Britton JH, Kozak UC \& Wells JM. The mitochondrial uncoupling protein gene. Correlation of exon structure to transmembrane domains. Journal of Biological Chemistry 1988 263 12274-12277.

40 Cassard AM, Bouillaud F, Mattei MG, Hentz E, Raimbault S, Thomas M \& Ricquier D. Human uncoupling protein gene: structure, comparison with rat gene, and assignment to the long arm of chromosome 4. Journal of Cellular Biochemistry 199043 255-264. 
41 Gong DW, He Y, Karas M \& Reitman M. Uncoupling protein-3 is a mediator of thermogenesis regulated by thyroid hormone, beta3adrenergic agonists, and leptin. Journal of Biological Chemistry $199727224129-24132$.

42 Boss O, Samec S, Kühne F, Bijlenga P, Assimacopoulos-Jeannet F, Seydoux J, Giacobino JP \& Muzzin P. Uncoupling protein-3 expression in rodent skeletal muscle is modulated by food intake but not by changes in environmental temperature. Journal of Biological Chemistry 1998273 5-8.

43 Ricquier D, Casteilla L \& Bouillaud F. Molecular studies of the uncoupling protein. FASEB Journal 19915 2237-2242.

44 Silva JE \& Rabelo R. Regulation of the uncoupling protein gene expression. European Journal of Endocrinology 1997136251 264.

45 Mory G, Bouillaud F, Combes-George M \& Ricquier D. Noradrenaline controls the concentration of the uncoupling protein in brown adipose tissue. FEBS Letters $1984166393-$ 396.

46 Ricquier D, Bouillaud F, Toumelin P, Mory G, Bazin R, Arch J \& Penicaud L. Expression of uncoupling protein mRNA in thermogenic or weakly thermogenic brown adipose tissue. Evidence for a rapid beta-adrenoreceptor-mediated and transcriptionally regulated step during activation of thermogenesis. Journal of Biological Chemistry 1986261 13905-13910.

47 Muzzin P, Revelli JP, Ricquier D, Meier MK, AssimacopoulosJeannet $\mathrm{F} \&$ Giacobino JP. The novel thermogenic betaadrenergic agonist Ro 16-8714 increases the interscapular brown-fat beta-receptor-adenylate cyclase and the uncouplingprotein mRNA level in obese $(f a / f a)$ Zucker rats. Biochemical Journal $1989261721-724$.

48 Rehnmark S, Nechad M, Herron D, Cannon B \& Nedergaard J. Alpha- and beta-adrenergic induction of the expression of the uncoupling protein thermogenin in brown adipocytes differentiated in culture. Journal of Biological Chemistry 1990265 16464-16471.

49 Savontaus E, Raasmaja A, Rouru J, Koulu M, Pesonen U, Virtanen R, Savola JM \& Huupponen R. Anti-obesity effect of MPV-1743 A III, a novel imidazoline derivative, in genetic obesity. European Journal of Pharmacology 1997328 207-215.

50 Bianco AC \& Silva JE. Cold exposure rapidly induces virtual saturation of brown adipose tissue nuclear T3 receptors. American Journal of Physiology 1988255 E496-E503.

51 Silva JE. Full expression of uncoupling protein gene requires the concurrence of norepinephrine and triiodothyronine. Molecular Endocrinology 19882 706-713.

52 Cassard-Doulcier AM, Larose M, Matamala JC, Champigny O, Bouillaud F \& Ricquier D. In vitro interactions between nuclear proteins and uncoupling protein gene promoter reveal several putative transactivating factors including Ets1, retinoid $\mathrm{X}$ receptor, thyroid hormone receptor, and a CACCC box-binding protein. Journal of Biological Chemistry $199426924335-$ 24342.

53 Alvarez R, de Andres J, Yubero P, Vinas O, Mampel T, Iglesias R, Giralt M \& Villarroya F. A novel regulatory pathway of brown fat thermogenesis. Retinoic acid is a transcriptional activator of the mitochondrial uncoupling protein gene. Journal of Biological Chemistry 1995270 5666-5673.

54 Puigserver P, Vazquez F, Bonet ML, Pico C \& Palou A. In vitro and in vivo induction of brown adipocyte uncoupling protein (thermogenin) by retinoic acid. Biochemical Journal 1996317 $827-833$

55 Foellmi-Adams LA, Wyse BM, Herron D, Nedergaard J \& Kletzien RF. Induction of uncoupling protein in brown adipose tissue. Synergy between norepinephrine and pioglitazone, an insulinsensitizing agent. Biochemical Pharmacology 199652 693701.

56 Paulik MA \& Lenhard JM. Thiazolidinediones inhibit alkaline phosphatase activity while increasing expression of uncoupling protein, deiodinase, and increasing mitochondrial mass in C3H10T1/2 cells. Cell and Tissue Research $199729079-87$.
57 Digby JE, Montague CT, Sewter CP, Sanders L, Wilkison WO, O'Rahilly S \& Prins JB. Thiazolidinedione exposure increases the expression of uncoupling protein 1 in cultured human preadipocytes. Diabetes $199847138-141$.

58 Larkin S, Mull E, Miao W, Pittner R, Albrandt K, Moore C, Young A, Denaro M \& Beaumont K. Regulation of the third member of the uncoupling protein family, UCP3, by cold and thyroid hormone. Biochemical and Biophysical Research Communications $1997240222-227$.

59 Boss O, Samec S, Dulloo A, Seydoux J, Muzzin P \& Giacobino JP. Tissue-dependent upregulation of rat uncoupling protein-2 expression in response to fasting or cold. FEBS Letters 1997 $412111-114$.

60 Millet L, Vidal H, Andreelli F, Larrouy D, Riou JP, Ricquier D, Laville M \& Langin D. Increased uncoupling protein-2 and -3 mRNA expression during fasting in obese and lean humans. Journal of Clinical Investigation 1997100 2665-2670.

61 Dulloo AG \& Girardier L. Adaptive changes in energy expenditure during refeeding following low-calorie intake: evidence for a specific metabolic component favoring fat storage. American Journal of Clinical Nutrition 199052 415-420.

62 Dulloo AG, Seydoux J \& Girardier L. Dissociation of enhanced efficiency of fat deposition during weight recovery from sympathetic control of thermogenesis. American Journal of Physiology 1995269 R365-R369.

63 Boss O, Samec S, Desplanches D, Mayet MH, Seydoux J, Muzzin P \& Giacobino JP. Effect of endurance training on mRNA expression of uncoupling proteins 1,2 , and 3 in the rat. FASEB Journal 199812 335-339.

64 Herlihy JT, Stacy C \& Bertrand HA. Long-term food restriction depresses serum thyroid hormone concentrations in the rat. Mechanisms of Ageing and Development 199053 9-16.

65 Oberkotter LV \& Rasmussen KM. Changes in plasma thyroid hormone concentrations in chronically food-restricted female rats and their offspring during suckling. Journal of Nutrition 1992122 435-441.

66 Cokelaere M, Decuypere E, Flo G, Darras VM \& Kuhn ER. Influence of feeding pattern on thyroid hormones in long-term food-restricted rats. Hormone and Metabolic Research 199628 315-318.

67 Weigle DS, Selfridge LE, Schwartz MW, Seeley RJ, Cummings DE, Havel PJ, Kuijper JL \& Beltrandel Rio H. Elevated free fatty acids induce uncoupling protein 3 expression in muscle. Diabetes 1998 47 298-302.

68 Shimabukuro M, Zhou YT, Lee Y \& Unger RH. Induction of uncoupling protein-2 mRNA by troglitazone in the pancreatic islets of Zucker diabetic fatty rats. Biochemical and Biophysical Research Communications 1997237 359-361.

69 Aubert J, Champigny O, Saint-Marc P, Negrel R, Collins S, Ricquier D \& Ailhaud G. Up-regulation of UCP-2 gene expression by PPAR agonists in preadipose and adipose cells. Biochemical and Biophysical Research Communications 1997238 606-611.

70 Camirand A, Marie V, Rabelo R \& Silva JE. Thiazolidinediones stimulate uncoupling protein-2 expression in cell lines representing white and brown adipose tissues and skeletal muscle. Endocrinology $1998139428-431$.

71 Sears IB, MacGinnitie MA, Kovacs LG \& Graves RA. Differentiationdependent expression of the brown adipocyte uncoupling protein gene: regulation by peroxisome proliferator-activated receptor gamma. Molecular and Cellular Biology 199616 3410-3419.

72 Miroux B, Frossard V, Raimbault S, Ricquier D \& Bouillaud F. The topology of the brown adipose tissue mitochondrial uncoupling protein determined with antibodies against its antigenic sites revealed by a library of fusion proteins. EMBO Journal 199312 3739-3745.

73 Lin CS \& Klingenberg M. Characteristics of the isolated purine nucleotide binding protein from brown fat mitochondria. Biochemistry 198221 2950-2956.

74 Rial E, Poustie A \& Nicholls DG. Brown-adipose-tissue mitochondria: the regulation of the $32000-\mathrm{Mr}$ uncoupling protein by 
fatty acids and purine nucleotides. European Journal of Biochemistry $1983137197-203$.

75 Strieleman PJ, Schalinske KL \& Shrago E. Fatty acid activation of the reconstituted brown adipose tissue mitochondria uncoupling protein. Journal of Biological Chemistry $1985260 \quad 13402-$ 13405.

76 Cunningham SA, Wiesinger H \& Nicholls DG. Quantification of fatty acid activation of the uncoupling protein in brown adipocytes and mitochondria from the guinea-pig. European Journal of Biochemistry 1986157 415-420.

77 Skulachev VP. Fatty acid circuit as a physiological mechanism of uncoupling of oxidative phosphorylation. FEBS Letters 1991 294 158-162.

78 Strieleman PJ \& Shrago E. Specific interaction of fatty acyl-CoA esters with brown adipose tissue mitochondria. American Journal of Physiology 1985248 E699-E705.

79 Katiyar SS \& Shrago E. Differential interaction of fatty acids and fatty acyl CoA esters with the purified/reconstituted brown adipose tissue mitochondrial uncoupling protein. Biochemical and Biophysical Research Communications 1991175 1104-1111.

80 Skulachev VP. Fatty acid circuit as a physiological mechanism of uncoupling of oxidative phosphorylation. FEBS Letters 1991 294 158-162.

81 Garlid KD, Orosz DE, Modriansky M, Vassanelli S \& Jezek P. On the mechanism of fatty acid-induced proton transport by mitochondrial uncoupling protein. Journal of Biological Chemistry $19962712615-2620$.

82 Winkler E \& Klingenberg M. Effect of fatty acids on $\mathrm{H}^{+}$transport activity of the reconstituted uncoupling protein. Journal of Biological Chemistry $19942692508-2515$.

83 Gonzalez-Barroso MM, Fleury C, Arechaga I, Zaragoza P, LeviMeyrueis C, Raimbault S, Ricquier D, Bouillaud F \& Rial E. Activation of the uncoupling protein by fatty acids is modulated by mutations in the C-terminal region of the protein. European Journal of Biochemistry 1996239 445-450.

84 Viguera AR, Goni FM \& Rial E. The uncoupling protein from brown adipose tissue mitochondria. The environment of the tryptophan residues as revealed by quenching of the intrinsic fluorescence. European Journal of Biochemistry $1992210893-$ 899.

85 Winkler E \& Klingenberg M. Photoaffinity labeling of the nucleotide-binding site of the uncoupling protein from hamster brown adipose tissue. European Journal of Biochemistry 1992203 295-304.

86 Mayinger P \& Klingenberg M. Labeling of two different regions of the nucleotide binding site of the uncoupling protein from brown adipose tissue mitochondria with two ATP analogs. Biochemistry 199231 10536-10543.

87 Murdza-Inglis DL, Modriansky M, Patel HV, Woldegiorgis G, Freeman KB \& Garlid KD. A single mutation in uncoupling protein of rat brown adipose tissue mitochondria abolishes GDP sensitivity of $\mathrm{H}^{+}$transport. Journal of Biological Chemistry 1994 $2697435-7438$.

88 Bouillaud F, Arechaga I, Petit PX, Raimbault S, Levi-Meyrueis C, Casteilla L, Laurent M, Rial E \& Ricquier D. A sequence related to a DNA recognition element is essential for the inhibition by nucleotides of proton transport through the mitochondrial uncoupling protein. EMBO Journal 199413 1990-1997.

89 Winkler E, Wachter E \& Klingenberg M. Identification of the $\mathrm{pH}$ sensor for nucleotide binding in the uncoupling protein from brown adipose tissue. Biochemistry 199736 148-155.

90 Echtay KS, Bienengraeber M \& Klingenberg M. Mutagenesis of the uncoupling protein of brown adipose tissue. Neutralization of E190 largely abolishes $\mathrm{pH}$ control of nucleotide binding. Biochemistry 199736 8253-8260.

91 Modriansky M, Murdza-Inglis DL, Patel HV, Freeman KB \& Garlid KD. Identification by site-directed mutagenesis of three arginines in uncoupling protein that are essential for nucleotide binding and inhibition. Journal of Biological Chemistry 1997272 2475924762 .
92 Gonzalez-Barroso MM, Fleury C, Levi-Meyrueis C, Zaragoza P, Bouillaud F \& Rial E. Deletion of amino acids 261-269 in the brown fat uncoupling protein converts the carrier into a pore. Biochemistry 199736 10930-10935.

93 Skulachev VP. Role of uncoupled and non-coupled oxidations in maintenance of safely low levels of oxygen and its one-electron reductants. Quarterly Reviews of Biophysics 199629 169-202.

94 Negre-Salvayre A, Hirtz C, Carrera G, Cazenave R, Troly M, Salvayre R, Penicaud L \& Casteilla L. A role for uncoupling protein-2 as a regulator of mitochondrial hydrogen peroxide generation. FASEB Journal 199711 809-815.

95 Soejima A, Inoue K, Takai D, Kaneko M, Ishihara H, Oka Y \& Hayashi JI. Mitochondrial DNA is required for regulation of glucose-stimulated insulin secretion in a mouse pancreatic beta cell line, MIN6. Journal of Biological Chemistry $199627126194-$ 26199.

96 Nilsson T, Schultz V, Berggren PO, Corkey BE \& Tornheim K. Temporal patterns of changes in ATP/ADP ratio, glucose 6-phosphate and cytoplasmic free $\mathrm{Ca}^{2+}$ in glucose-stimulated pancreatic beta-cells. Biochemical Journal 1996314 91-94.

97 Zhou YT, Shimabukuro M, Koyama K, Lee Y, Wang MY, Trieu F, Newgard CB \& Unger RH. Induction by leptin of uncoupling protein-2 and enzymes of fatty acid oxidation. Proceedings of the National Academy of Sciences of the USA 199794 6386-6390.

98 Koyama K, Chen G, Wang MY, Lee Y, Shimabukuro M, Newgard $\mathrm{CB}$ \& Unger RH. Beta-cell function in normal rats made chronically hyperleptinemic by adenovirus-leptin gene therapy. Diabetes 199748 1276-1280.

99 Shimabukuro M, Zhou YT, Lee Y \& Unger RH. Induction of uncoupling protein-2 mRNA by troglitazone in the pancreatic islets of Zucker diabetic fatty rats. Biochemical and Biophysical Research Communications 1997237 359-361.

100 Lowell BB, Susulic VS, Hamann A, Lawitts JA, Himms-Hagen J, Boyer BB, Kozak LP \& Flier JS. Development of obesity in transgenic mice after genetic ablation of brown adipose tissue. Nature $1993366740-742$.

101 Hamann A, Flier JS \& Lowell BB. Decreased brown fat markedly enhances susceptibility to diet-induced obesity, diabetes, and hyperlipidemia. Endocrinology 1996137 21-29.

102 Kopecky J, Clarke G, Enerback S, Spiegelman B \& Kozak LP. Expression of the mitochondrial uncoupling protein gene from the aP2 gene promoter prevents genetic obesity. Journal of Clinical Investigation $1995962914-2923$.

103 Enerback S, Jacobsson A, Simpson EM, Guerra C, Yamashita H, Harper ME \& Kozak LP. Mice lacking mitochondrial uncoupling protein are cold-sensitive but not obese. Nature 1997 387 90-94.

104 Oppert JM, Vohl MC, Chagnon M, Dionne FT, Cassard-Doulcier AM, Ricquier D, Perusse L \& Bouchard C. DNA polymorphism in the uncoupling protein (UCP) gene and human body fat. International Journal of Obesity and Related Metabolic Disorders $199418526-531$.

105 Cassard-Doulcier AM, Bouillaud F, Chagnon M, Gelly C, Dionne FT, Oppert JM, Bouchard C, Chagnon Y \& Ricquier D. The Bcl I polymorphism of the human uncoupling protein (ucp) gene is due to a point mutation in the 5'-flanking region. International Journal of Obesity and Related Metabolic Disorders $199620278-$ 279.

106 Clement K, Ruiz J, Cassard-Doulcier AM, Bouillaud F, Ricquier D, Basdevant A, Guy-Grand B \& Froguel P. Additive effect of A->G $(-3826)$ variant of the uncoupling protein gene and the Trp64Arg mutation of the beta 3-adrenergic receptor gene on weight gain in morbid obesity. International Journal of Obesity and Related Metabolic Disorders $1996201062-1066$.

107 Fumeron F, Durack-Bown I, Betoulle D, Cassard-Doulcier AM, Tuzet S, Bouillaud F, Melchior JC, Ricquier D \& Apfelbaum M. Polymorphisms of uncoupling protein (UCP) and beta 3 adrenoreceptor genes in obese people submitted to a low calorie diet. International Journal of Obesity and Related Metabolic Disorders $1996201051-1054$. 
108 Urhammer SA, Fridberg M, Sorensen TI, Echwald SM, Andersen T, Tybjaerg-Hansen A, Clausen JO \& Pedersen O. Studies of genetic variability of the uncoupling protein 1 gene in Caucasian subjects with juvenile-onset obesity. Journal of Clinical Endocrinology and Metabolism 199782 4069-4074.

109 Bouchard C, Perusse L, Chagnon YC, Warden C \& Ricquier D. Linkage between markers in the vicinity of the uncoupling protein 2 gene and resting metabolic rate in humans. Human Molecular Genetics 19976 1887-1889.

110 Elbein SC, Leppert M \& Hasstedt S. Uncoupling protein 2 region on chromosome 11q13 is not linked to markers of obesity in familial type 2 diabetes. Diabetes 199746 2105-2107.

111 Urhammer SA, Dalgaard LT, Sorensen TI, Moller AM, Andersen T, Tybjaerg-Hansen A, Hansen T, Clausen JO, Vestergaard H \& Pedersen $O$. Mutational analysis of the coding region of the uncoupling protein 2 gene in obese NIDDM patients: impact of a common amino acid polymorphism on juvenile and maturity onset forms of obesity and insulin resistance. Diabetologia 1997 40 1227-1230.

112 Dulloo AG \& Miller DS. Obesity: a disorder of the sympathetic nervous system. World Review of Nutrition and Dietetics 198750 $1-56$.

113 Bouchard C \& Perusse L. Current status of the human obesity gene map. Obesity Research 19964 81-90.

114 Wiesinger H, Klaus S, Heldmaier G, Champigny O \& Ricquier D. Increased nonshivering thermogenesis, brown fat cytochrome-c oxidase activity, GDP binding, and uncoupling protein mRNA levels after short daily cold exposure of Phodopus sungorus. Canadian Journal of Physiology and Pharmacology 199068 195200.

115 Ashwell M, Jennings G, Richard D, Stirling DM \& Trayhurn P. Effect of acclimation temperature on the concentration of the mitochondrial 'uncoupling' protein measured by radioimmunoassay in mouse brown adipose tissue. FEBS Letters 1983161 108-112.

116 Trayhurn P, Ashwell M, Jennings G, Richard D \& Stirling DM. Effect of warm or cold exposure on GDP binding and uncoupling protein in rat brown fat. American Journal of Physiology 1987 252 E237-E243.

117 Himms-Hagen J \& Villemure C. Number of mice per cage influences uncoupling protein content of brown adipose tissue. Proceedings of the Society for Experimental Biology and Medicine $1992200502-506$.

118 Champigny $\mathrm{O} \&$ Ricquier D. Effects of fasting and refeeding on the level of uncoupling protein mRNA in rat brown adipose tissue: evidence for diet-induced and cold-induced responses. Journal of Nutrition $19901201730-1736$.

119 Knott RM, Trayhurn P \& Hesketh JE. Changes in insulin-receptor mRNA levels in skeletal muscle and brown adipose tissue of weanling rats during fasting and refeeding. British Journal of Nutrition 199268 583-592.

120 Matamala JC, Gianotti M, Pericas J, Quevedo S, Roca P, Palou A \& Garcia-Palmer FJ. Changes induced by fasting and dietetic obesity in thermogenic parameters of rat brown adipose tissue mitochondrial subpopulations. Biochemical Journal 1996319 529-534.

121 Scarpace PJ, Matheny M, Pollock BH \& Tumer N. Leptin increases uncoupling protein expression and energy expenditure. American Journal of Physiology 1997273 E226-E230.

122 Giraudo SQ, Kotz CM, Grace MK, Levine AS \& Billington CJ. Rat hypothalamic NPY mRNA and brown fat uncoupling protein mRNA after high-carbohydrate or high-fat diets. American Journal of Physiology 1994266 R1578-R1583.
123 Scarpace PJ, Yenice S \& Tumer N. Influence of exercise training and age on uncoupling protein mRNA expression in brown adipose tissue. Pharmacology, Biochemistry and Behavior 199449 1057-1059.

124 Bianco AC \& Silva JE. Intracellular conversion of thyroxine to triiodothyronine is required for the optimal thermogenic function of brown adipose tissue. Journal of Clinical Investigation 198779 295-300.

125 Obregon MJ, Pitamber R, Jacobsson A, Nedergaard J \& Cannon B. Euthyroid status is essential for the perinatal increase in thermogenin mRNA in brown adipose tissue of rat pups. Biochemical and Biophysical Research Communications 1987148 9-14.

126 Moriscot A, Rabelo R \& Bianco AC. Corticosterone inhibits uncoupling protein gene expression in brown adipose tissue. American Journal of Physiology 1993265 E81-E87.

127 Strack AM, Horsley CJ, Sebastian RJ, Akana SF \& Dallman MF. Glucocorticoids and insulin: complex interaction on brown adipose tissue. American Journal of Physiology 1995268 R1209-R1216.

128 Strack AM, Bradbury MJ \& Dallman MF. Corticosterone decreases nonshivering thermogenesis and increases lipid storage in brown adipose tissue. American Journal of Physiology 1995268 R183-R191.

129 Klaus S, Ely M, Encke D \& Heldmaier G. Functional assessment of white and brown adipocyte development and energy metabolism in cell culture. Dissociation of terminal differentiation and thermogenesis in brown adipocytes. Journal of Cell Science 1995 108 3171-3180.

130 Himms-Hagen J, Cui J, Danforth E Jr, Taatjes DJ, Lang SS, Waters BL \& Claus TH. Effect of CL-316,243, a thermogenic beta 3-agonist, on energy balance and brown and white adipose tissues in rats. American Journal of Physiology 1994266 R1371-R1382.

131 Nagase I, Yoshida T, Kumamoto K, Umekawa T, Sakane N, Nikami H, Kawada T \& Saito M. Expression of uncoupling protein in skeletal muscle and white fat of obese mice treated with thermogenic beta 3-adrenergic agonist. Journal of Clinical Investigation $1996972898-2904$.

132 Umekawa T, Yoshida T, Sakane N, Saito M, Kumamoto K \& Kondo M. Anti-obesity and anti-diabetic effects of CL316,243, a highly specific beta 3-adrenoceptor agonist, in Otsuka LongEvans Tokushima Fatty rats: induction of uncoupling protein and activation of glucose transporter 4 in white fat. European Journal of Endocrinology 1997136 429-437.

133 Matsuda J, Hosoda K, Itoh H, Son C, Doi K, Tanaka T, Fukunaga Y, Inoue G, Nishimura H, Yoshimasa Y, Yamori Y \& Nakao K. Cloning of rat uncoupling protein-3 and uncoupling protein-2 cDNAs: their gene expression in rats fed high-fat diet. FEBS Letters 1997418 200-204.

134 Surwit RS, Petro AE, Parekh P \& Collins S. Low plasma leptin in response to dietary fat in diabetes- and obesity- prone mice. Diabetes 199746 1516-1520.

135 Lanni A, De Felice M, Lombardi A, Moreno M, Fleury C, Ricquier D \& Goglia F. Induction of UCP2 mRNA by thyroid hormones in rat heart. FEBS Letters 1997418 171-174.

136 Masaki T, Yoshimatsu H, Kakuma T, Hidaka S, Kurokawa M \& Sakata T. Enhanced expression of uncoupling protein 2 gene in rat white adipose tissue and skeletal muscle following chronic treatment with thyroid hormone. FEBS Letters 1997418 323326.

Received 12 February 1998

Accepted 5 March 1998 